\title{
On Some Disputable Issues of Reference for Preliminary Ruling Regulations and about the Mandatory Nature for Bulgarian Courts of the Court of Justice of European Union's Judgment on Reference for Preliminary Ruling
}

\author{
Atanas Simeonov Ivanov* PhD \\ Assistant in scientific degree "Civil Litigation" at South-Western University "Neofit Rilski"- Blagoevgrad, \\ Bulgaria; Judge at Blagoevgrad Regional Court.
}

*Corresponding Author: Atanas Simeonov Ivanov, Assistant in scientific degree "Civil Litigation" at South-Western University "Neofit Rilski”- Blagoevgrad, Bulgaria; Judge at Blagoevgrad Regional Court

\begin{abstract}
Community law is individual legal order acting parallel with the national law on the territory of member-states1, as the reference for preliminary ruling's conclusions aim to guarantee uniform applying of community norms on the entire territory of the European Union. In this sense, the possibility or withholding of the tribunal - the Bulgarian court, arises from the date of the Treaty of Accession - 1st of January 2007, which obligations results directly from the operation of art. 234 of Treaty establishing the European Community, now art. 267 of Treaty on the Functioning of the European Union.
\end{abstract}

Keywords: Court, Judgment, Reference for Preliminary Ruling, European Community, Legal Proceedings.

\section{INTRODUCTION}

The membership of Republic of Bulgaria in the European Union preconditions the integration of the Community legal order in the national legal system while observing the established principles for its application - immediate operation, primacy and direct effect. Under argument from art. 628, in relation to art. 633 of Civil-Procedure Code, in cases when the Bulgarian court establishes that the interpretation of the Community norm or validity of deed of the EU authorities are of significance for the accurate solving of the raised dispute, it shall send an inquiry to the Court of Justice of European Union (CJEU) which judgment shall be compulsory for all national courts and institutions. The sooutlined correlation states that the preliminary ruling proceeding of CJEU on the case having regards to the scope of the specific national dispute, is a temporary negative procedural obstacle for the pending lawsuit's development. The same is deduced in the hypothesis of the provision of art. 229, par. 1, point 4 of the Civil-Procedure Code, the application of which is in particular dependent on the assessment of the direct relevance of the questions referred in the preliminary ruling proceeding. It is permissible the factual compositions on the case the inquiry was made for and the ones on the discontinued case to not be fully identical but necessary is to have similarity between them which to impose in the same context the applying of the respective Community legal norm, interpreted in the meaning given to it by CJEU. Due to this, the presence or lack of reference for preliminary ruling under art. 229, par. 1, point 4 of Civil-Procedure Code is liable to specific analysis in every separate case with review of facts and circumstances established on it by the parties of the dispute.

Republic of Bulgaria is a member of the European Union as of $1^{\text {st }}$ of January 2007, due to which the Community law is not applicable for legal relations incurred prior to the stated date. This conclusion does not change from the necessity to observe and interpret judgments by CJEU ruled prior to $1^{\text {st }}$ of January 2007 and in cases when they clarify the precise meaning of Community norms applicable past this moment or overlapping in contents, for their interpretation by the CJEU is incorporated in them from the day the deed has become effective. Definitive in the case is that those deeds are inapplicable for Bulgaria prior to its membership in the EU, due to which their primacy is excluded with regarding to national norms effective as at 2006. 
On Some Disputable Issues of Reference for Preliminary Ruling Regulations and about the Mandatory Nature for Bulgarian Courts of the Court of Justice of European Union's Judgment on Reference for Preliminary Ruling

The new Civil-Procedure Code is the first Bulgarian normative deed settling the reference for preliminary ruling before CJEU. The systematic place of the settlement of reference for preliminary ruling is in part seven of the Civil-Procedure Code, titled "Special rules regarding civil cases proceedings upon operation of the European Union law". This is because civil cases are reviewed only by courts, the settlement in Civil-Procedure Code is only for reference for preliminary ruling which are sent to CJEU by civil courts.

The provisions of art. 267 of Treaty on the Functioning of the European Union (TFEU) regulate that inquiries may be sent by all national jurisdictions meeting the criteria set by CJEU. On the other hand, the possibility, respectively the obligation for sending preliminary ruling proceeding depends on the type of case which is reviewed before the national body ${ }^{1}$.

The Community law is an individual legal order which acts in parallel with the national law on the territory of member-states ${ }^{2}$, as the preliminary ruling proceeding has main function to guarantee the uniform applying of Community norms on the entire territory of European Union. In this sense, the possibility or obligation of the judicial body - the Bulgarian court, incurs as of the date of the Treaty of Accession entering into force $-1^{\text {st }}$ of January 2007 which obligation directly results from the operation of art. 234 of Treaty establishing the European Community, now art. 267 of Treaty on the Functioning of the European Union. This is why the regulations about reference for preliminary ruling in the Civil-Procedure Code in its most part is unnecessary because upon free telling of the respective Community norms and case law of CJEU may affect the principle of immediate applicable of the Community law.

In accordance with the provisions of art. 628 of Civil-Procedure Code, liable to interpretation are the "provisions of the European Union law" and "deed by European Union authorities". Validity estimate may be requested with regards to deeds of "European union authorities". Relatable community norms, applicable in this case, are the first paragraph of art. 267 of Treaty on the Functioning of the European Union, the first paragraph of art. 150 of Treaty establishing the European Atomic Energy Community and art. 46 of Treaty on European Union. Therefore, besides the constituent treaties, liable to interpretation are also the treaties amending them as well as the treaties for co-joining other memberstates (Bului 2002:49-50 and the legal case laws referred there). The case law allows interpretation of international treaties concluded by the Council (Bului 2002:50-51 and legal case law referred there).

The provisions of art. 629 of Civil-Procedure Code is the core of Bulgarian regulations about reference for preliminary ruling and set most issues. Its revision discloses the non-understanding of the preliminary rulings by the Bulgarian legislative body and the ignorance of the CJEU's case law in the matter reviewed.

Present is independence in the national court regarding the request of case's parties for sending reference for preliminary ruling. Solely competent to estimate the necessity and send reference for preliminary rulings to CJEU are the national jurisdictions. This follows from the explicit revision of art. 267 of Treaty on the Functioning of the European Union as well as from the permanent case law of CJEU. The parties in the proceedings may not turn to CJEU directly with request for ruling a preliminary judgment ${ }^{3}$. Besides, they, in no way can affect the formulation and contents of the preliminary ruling's issues with regards to which national jurisdiction has exclusive powers ${ }^{4}$. National court is not bound by a party's request for sending reference for preliminary ruling 5 .

In essence, the first three paragraphs of art. 629 of Civil-Procedure Code follow this logic. Pursuant to art. 629, par. 1 of Civil-Procedure Code the request is sent officially or upon request by the parties. It is pointless, in the second paragraph of art. 629 of the Civil-Procedure Code to state that the national

\footnotetext{
${ }^{1}$ See Judgment dated 21.03.1972, S.A.I.L., Rec. 1972, p. 119.

${ }^{2}$ So as Judgment 15.07.1964, COSTA|E.N.E.L. 6|64, Rec. 1964, p. 1141.

3 Judgment dated 14.12.1962, Wohrmann/Commission EEC, 31/62 and 33/62, Rec. 1962, p. 965; Judgment dated 9.12.1965, Hessische Knappschaft/Singer et Fils, 44/65, Rec. 1965, p. 1191; Judgment dated 15.6.1972, Grassi/Amministrazione delle finanze dello Stato, 5/72, Rec. 1972, p. 443; Judgment dated 22.11.1978, Mattheus/Doego, 93/78, Rec. 1978, p. 2203; Judgment dated 29.11.1978, Redmond, 83/78, Rec. 1978, p. 2347. ${ }^{4}$ Judgment dated 5.10.1988, Alsatel/Novasam, 247/86, Rec. 1988, p. 5987.

${ }^{5}$ Hessische Knappschaft/Singer et Fils, quoted above.
} 
On Some Disputable Issues of Reference for Preliminary Ruling Regulations and about the Mandatory Nature for Bulgarian Courts of the Court of Justice of European Union's Judgment on Reference for Preliminary Ruling

court may not grant a request from a party to the referral case to the CJEU. This results from the basic principles that govern the cooperation and interaction between national jurisdictions and the CJEU, which interpretation or clarification is not among the powers of the Bulgarian legislator.

Even if the civil court reviews the case as a last instance, it will not be bound by the request of dispute's parties regarding referral of the issue to be interpreted by CJEU. On one hand, it may decide that present is some of the special hypothesis which release it of this obligation, and on the other even if wrong in its estimate, the sanction will be expressed in establishing the breach of the memberstate under art. 258 and following of Treaty on the Functioning of the European Union or engaging in non-contractual responsibility of the country and not through its subordination to the will of case's parties.

According to Art. 629, par. 3 "the court which decision is not subject to appeal always asks for interpretation unless the answer to the issue is clear and unambiguous from a previous judgment of the Court of Justice or the meaning and sense of the provision or deed are so clear that they do not evoke any doubt." In order to assess the compatibility and, in general, the usefulness of that provision, it is necessary to briefly clarify the situations in which the national courts have a duty to make a reference for a preliminary ruling. National jurisdiction, which is dealing with a legal dispute as a last instance, is required to bring an action before the CJEU if a Community rule is to be applied in resolving this dispute, and that Community rule needs to be interpreted. The third paragraph of art. 267 TFEU does not allow any exceptions to that obligation. As that provision falls within the scope of the CJEU's interpretative competence, it has been able, in its case law, to provide for cases in which the national court may be exempted from the obligation to make a request.

In the Hoffmann-La Roche judgment, the CJEU takes the view that the national court is not required to refer an issue of interpretation to the Court of Justice when it is raised in the context of an accelerated procedure for the imposition of interim measures even if there is no possibility of challenging the decision which must be given, provided that either party may initiate or request the initiation of proceedings on the merits, within which the question of the provisionally permitted in the accelerated procedure may be reconsidered and may be the subject of an inquiry by virtue of art. $267^{6}$.

With the judgment on the CILFIT $T^{7}$ case CJEU extends the hypothesis where national courts, reviewing a dispute as a last instance, are exempted from the obligation to send reference for preliminary ruling.

First of all, the national jurisdiction may not call CJEU when the issue raised is materially identical to an issue having already been a subject of preliminary rulings. Then, the obligation for making the reference fails when the legal dispute was resolved through CJEU's permanently established case law, regardless of the proceeding, within which this case law is ruled, even if the matters are not identical. Lastly, the national court may not observe the obligation to send inquiry when the accurate applying of the Community law is so obvious that leaves no reasonable doubt regarding the interpretation of the respective Community norm.

In the last case CJEU bounds national jurisdictions with the execution of preliminary inspection whether the situation is so obvious for the jurisdictions of other member-states and for the CJEU itself. Besides, because of various language versions of the Community law sources being equally authentic, the respective court shall compare them and then decide whether the Community norm's meaning is obvious.

The aforementioned clarifies that, despite the principle of legal acuity, the literal interpretation of the CJEU's requirements raises insurmountable barriers to its applicability. Without underestimating the capabilities of the Bulgarian judiciary, it seems to me that, in the main dispute, it is not common sense to compare all the language versions of the Community deed and, even less, to assess the obviousness of the meaning of the rule in relation to the jurisdictions of the other member-states. Obviously, that requirement was introduced only to strengthen the obligation of the national court to take account of

\footnotetext{
${ }^{6}$ So as Judgment dated 27.10.1982, Morson and Jhanjan/Netherlands State, 35/82 and 36/82, Rec. 1982, p. 3723.

${ }^{7}$ Judgment dated 6.10.1982, CILFIT/Ministero della Sanita, 283/81, Rec. 1982, p. 3415.
} 
On Some Disputable Issues of Reference for Preliminary Ruling Regulations and about the Mandatory Nature for Bulgarian Courts of the Court of Justice of European Union's Judgment on Reference for Preliminary Ruling

the context and objectives set out in the considerations of the relevant Community deed ${ }^{8}$.

Established is CJEU's case law with review the obligation to referral and exemptions thereof.

First of all, the obligation for referral incurs only if for solving of respective legal dispute applied may be the Community norm which is unclear.

Second of all, despite the applicability of some of the exceptions for mandatory referral, the national jurisdiction is not bound by any of them and may always discontinue the case and send reference for preliminary ruling.

Thirdly, failure to comply with the obligation to bring proceedings may entail both a breach of the contractual obligations of the member-state to which the relevant judicial authority belongs and noncontractual liability for damage caused to individuals. In this sense, the national court shall be extremely careful when resorting to any of the exceptions (Wattel 2004).

It is clear from the brief presentation of the CJEU's case law that the provision of art. 629, par. 3 of Civil-Procedure Code is badly edited, it does not exhaust all possible exceptions from the obligation to refer and regulates at national level a matter that is not within the competence of the Bulgarian legislator. Therefore, de lege ferenda it should be revoked.

According to art. 267 of TFEU, the subject of the preliminary ruling procedure are two different-inessence matters. Those are, on one hand, the questions which seek to interpret the Community rules applicable to the main and secondary legislation applicable in the main proceedings. On the other hand, a preliminary question may be asked by the CJEU to declare the invalidity of rules of secondary law. Interpretational queries and validation queries are subject to the same rules as are dealt with in the art. 267 of TFEU itself.

Pursuant to art. 629, par. 1 of Civil-Procedure Code the national court shall send inquiry every time when an issue is set about the validity of institution's deed or deed by the European Central Bank. Of this formulation follows that this obligation will be on all civil courts, regardless whether reviewing the case as last instance or not.

According to art. 267 of TFEU, the optional or mandatory nature of a reference for a preliminary ruling depends not on its subject-matter (for interpretation or on the assessment of validity) but on whether or not the decision of the court is amenable to review. Western European doctrine supports this interpretation of the TFEU (Bului 2002: 31-32, Arnull 2006: 125, Hartley 2003: 289). The Court of Justice of the European Union has explicitly ruled on the scope of the request for validity in the Foto-Frost ${ }^{9}$ judgment. That decision allocates the powers between the CJEU and the national courts in assessing the validity of Community deed. The CJEU concedes that the national courts which decisions are open to challenge may reject the parties' allegations that the Community deed is invalid and confirm its validity. However, if the national courts have doubts as to the validity of the measure, they are not competent to declare its invalidity, but are required to make a reference for a preliminary ruling.

Obviously the provisions of art. 629, par. 4 of Civil-Procedure Code severely differ from the interpretation of the nature of validity inquiry, adopted by the CJEU, which I find is due to inaccurate referral to the CJEU's instructions on legislator's part.

In general, the obligation for reference for preliminary ruling to CJEU is binding for the national courts, which are dealing with litigation as a last instance. The purpose of the cooperation soestablished is to ensure the uniform application of Community law throughout the territory of all member-states. To be able to do so, the TFEU has retained the activity of interpreting the Community rules in the exclusive competence of the CJEU. At the same time, the cases in which the national courts may or shall make a reference for a preliminary ruling are distinguished. If all jurisdictions were required to make a reference for a preliminary ruling whenever an issue of interpretation of a

\footnotetext{
${ }^{8}$ In this sense, conclusion by general attorney Jacobs on case Wiener / Hauptzollamt Emmerich, C- 338/95, Rec. 1997, p. I-6495.

${ }^{9}$ Judgment dated 22.10.1987, Foto-Frost/Hauptzollamt Lubeck-Ost, 314/85, Rec. 1987, p. 4199.
} 
On Some Disputable Issues of Reference for Preliminary Ruling Regulations and about the Mandatory Nature for Bulgarian Courts of the Court of Justice of European Union's Judgment on Reference for Preliminary Ruling

Community rule was raised before them, the CJEU would be overwhelmed by such inquiries, which would affect the possibility of uniform application of Community law. The appeal of judgments and the obligation to refer the matter to the CJEU by the last national court provides sufficient guarantees as to the uniform application of Community law and the protection of individuals' rights.

Reviewed together, the provisions of art. art. 629-633 of Civil-Procedure Code govern the rules of the judicial deeds relating to the issue of a reference for a preliminary ruling. It should be noted that the determination of the content of the reference for a preliminary ruling is not a matter for the Bulgarian legislature. It is therefore more reasonable for the civil courts to ignore the rules in the CivilProcedure Code and, when formulating a reference for a preliminary ruling, to strictly follow the instructions of the CJEU to the national jurisdictions and, in particular, the CJEU's case-law on the preconditions for the admissibility of the references for a preliminary ruling. These are the only "legitimate sources" from which the necessary information may be obtained when making the relevant inquiry.

In view of the principle of the direct applicability of the Community norms, the new Civil-Procedure Code had to settle only two matters: what is the type of the deed making the reference and is it subject to appeal? The answer to the first matter remains unclear, even after multiple reading of the regulation of preliminary queries in the Civil-Procedure Code. Article 628 of Civil-Procedure Code, the five paragraphs of art. 629 of the Civil-Procedure Code, art. 630, par. 1 of Civil-Procedure Code, art. 631, par. 1 of the Civil-Procedure Code use the notion of "inquiry." When a civil court fails to grant a request to a party to make a reference for a preliminary ruling, it decides by a ruling, which follows from the systematic interpretation of the two sentences of art. 629, par. 2 of Civil-Procedure Code (the systematic interpretation of the two sentences of article 631, par. 1 of the Civil-Procedure Code), it is not clear from the current rules of the Civil-Procedure Code either the deed with which the request is made or how many orders are made by the court if it decides to make a preliminary ruling.

With review of the systematics of court deeds and Bulgarian procedural traditional, adopted shall be that the deed for reference for preliminary ruling is "order". In this order contained will be the issues which the national jurisdiction sends to CJEU and regarding to it is the mandatory contents which the legislator has tried to settle in art. 630 of Civil-Procedure Code.

It is possible the civil court to rule two orders - one where contained is the inquiry and another which suspends the proceedings on the case. With review of the formulation of proceedings in CivilProcedure Code I consider as more acceptable the courts to rule in one court deed regarding those two matters so there would be no doubt or contradiction with the common sense of its non-appeal. In two separate hypotheses the legislator joints the non-appeal of deeds related to sending reference for preliminary ruling. The first case is settled in art. 629, par. 2 of Civil-Procedure Code and regards to the non-appeal of the order with which the court refuses to respect request by a party for reference for preliminary ruling. This permission is accurate and in fact is only possible with review of the circumstance that only the national jurisdiction is competent to estimate whether to refer to CJEU or not. It in no way may be bound by request of dispute's parties. In this sense is the permanent case law of CJEU.

The second hypothesis is related to the non-appeal of the ruling on the suspension of the case. The legislator's idea is obviously to strengthen the discretion of the national jurisdiction whether there is a need for a ruling by the CJEU in order to be able to rule on the main dispute. In view of the abovementioned terminological imperfections, it is also possible to interpret this idea in retrospect. There is no provision in the Civil Procedure Code to regulate the appeal of the so-called "inquiry."

In accordance with art. 633 of Civil-Procedure Code the judgment of CJEU regarding reference for preliminary ruling is mandatory for all courts and establishments in Republic of Bulgaria. This provision is an impermissible exceeding the powers of the Bulgarian legislator. It is beyond its competence to determine the effect of a supranational jurisdiction. In the absence of an express provision of Community law on the legal force and effect of the judgments of the CJEU on direct actions and preliminary rulings, the task of the CJEU's doctrine and case law is to try to outline the scope of the decisions of the CJEU with regard to parties. 
On Some Disputable Issues of Reference for Preliminary Ruling Regulations and about the Mandatory Nature for Bulgarian Courts of the Court of Justice of European Union's Judgment on Reference for Preliminary Ruling

Besides the formulations of art. 633, par. 1 of Civil-Procedure Code raises bewilderment when compares to the provision of art. 297 of Civil-Procedure Code which determines the operation of the judgments effective for civil courts. There is no reasonable explanation of the circumstance that the CJEU's judgments are mandatory for the courts and institutions and the civil court's judgments bind also the municipalities.

Due to lack of community legal regulations on the issue being reviewed, the doctrine is not uniform when determining the subjects to be bound by the referral for preliminary ruling of CJEU. The CJEU itself is cautious when ruling regarding the operation of his judgments with regards to entities.

Preliminary ruling by CJEU is mandatory for the jurisdiction having sent the inquiry ${ }^{10}$. This binding force, however, shall be observed with review of the specifics of the preliminary ruling itself. National jurisdiction is bound by the ruling as far as it shall applying interpretative norm in the sense the CJEU has given it in its judgment. If CJEU has ruled that a certain Community norm is invalid, the authority having sent the inquiry shall be bound by this judgment. This, however, may in no way affect the capability of the same national jurisdiction to send a new referral for preliminary ruling within the same pending proceedings ${ }^{11}$.

CJEU's preliminary rulings bind not the parties of the main dispute but the national court sending the inquiry as well as all other national courts which will review this legal dispute within the instance control (Toth 1984:56).

Of course, in the light of interpreting art. 267, par. 3 of TFEU in the judgment on the CILFIT case the courts which judgments are not liable appeal may always "bind" themselves by a reference for preliminary ruling of CJEU without this affecting their freedom to enquire CJEU.

Different is the issue regarding the preliminary rulings establishing the invalidity of a Community norm. It follows from the inextricable connection which exists between the legal outcomes of those judgments and legal outcomes of judgments for revocation in the proceedings under art. 263 of TFEU. Evident of the CJEU's motives on the judgment regarding the International Chemical Corporation's ${ }^{12}$ case, then the court is forced, in accordance with art. 177 to announce the invalidity of an institution's deed towards the requirements for uniform applying of the Community law added are special imperative requirements related to legal certainty. From the nature of invalidity declaration itself follows that national jurisdiction may not apply the deed declared to be invalid without creating serious uncertainty regarding the applicable community law; Therefore, despite a Court's judgment under art. 177 of the Treaty declaring an institution's deed invalid (...), is directly addressed only to the national jurisdiction having referred the issue to Court, it is sufficient grounds for every other national jurisdiction to review this deed as invalid for the purposes of the judgment it shall rule; This concept, however, does not mean that national jurisdictions are deprived of the power granted by art. 177 of the Treaty. They shall estimate whether they shall raise an issue having already been reviewed by the Court and the Court has proclaimed the invalidity of public institution's deed (...); In the opposite case, national jurisdictions have grounds to extract for the needs of the dispute outcomes resulting of a judgment proclaiming invalidity by the Court in a dispute between other parties.

\section{CONCLuSiON}

The EU law, as directly applicable law, obliges the practicing jurist to observe it but also extends his horizon in terms of precise rulemaking and depth when protecting the rights of litigation's parties, establishes a feeling of unity between all interpreting legal norms aiming to raise the principle of legality throughout the EU. In its most part the reference for preliminary ruling regulations in the Civil-Procedure Code do not comply with the stated as we may even say it is unnecessary, violates the immediate applicability principle and even misleads Bulgarian courts. I find that the legislator should have settled only the deed for reference and the legal regimen of its appeal, but has not been done.

\footnotetext{
${ }^{10}$ Judgment dated 24.6.1969, Milch-, Fett- und Eierkontor / Hauptzollamt SaarbrUcken, 29/68, Rec. 1969, p. 165; Judgment dated 3.2.1977, Benedetti/Munari, 52/76, Rec. 1977, p. 163.

${ }^{11}$ Milch, Fett-und Eierkontor, Judgment dated 16.12.1981, FoglialNovelo № 2, 244/80, Rec. 1981, p. 3045

${ }^{12}$ Resolution dated 13.5.1981, International Chemical Corporation / Amministrazione delle fianze dello Stato, 66/80, Rec. 1981, p. 1191.
} 
On Some Disputable Issues of Reference for Preliminary Ruling Regulations and about the Mandatory Nature for Bulgarian Courts of the Court of Justice of European Union's Judgment on Reference for Preliminary Ruling

Unfortunately, this regulation is contradictive and needs accurate interpretation so it may be accurately applied by the courts. The general misunderstanding of the cooperation mechanism between CJEU and the national jurisdictions caused an increase of Bulgarian legislator's power. All of this requires immediate legislative intervention to reform the reference for preliminary proceeding in Civil-Procedure Code.

\section{REFERENCES}

[1] Bului, Zh., M. Darmon. 2002. Procedural law of European Communities. Sofia: Institute of International Law.

[2] Kornezov, Al. 2007. Definition for reference for preliminary ruling. Legal Thought, 4: 51-66.

[3] Kostov, St. 2006. Notion “member-state's jurisdiction" in the proceeding under art. 234 of Treaty establishing the European Community. Commercial law, 5: 81112.

[4] Arnull, A. 2006. The European Union and its Court of Justice. Oxford: Oxford University Press.

[5] Hartley, T. C. 2003. The Foundations of European Community Law. Oxford: Oxford University Press.

[6] Toth, A.G. 1984. The authority of Judgments of the European Court of Justice: Binding Force and Legal Effects. Yarbook of European Law, 4: 1-77.

[7] Wattel, P. 2004. Kobler, CILFIT and Welthgrove: We can't go on meeting like this. CML Rev, 41: 177191.

Citation: Atanas Simeonov Ivanov. "On Some Disputable Issues of Reference for Preliminary Ruling Regulations and about the Mandatory Nature for Bulgarian Courts of the Court of Justice of European Union's Judgment on Reference for Preliminary Ruling" International Journal of Humanities Social Sciences and Education (IJHSSE), vol 5, no. 8, 2018, pp. 112-118. doi: http://dx.doi.org/10. 20 431/2349-0381.0508013.

Copyright: () 2018 Authors. This is an open-access article distributed under the terms of the Creative Commons Attribution License, which permits unrestricted use, distribution, and reproduction in any medium, provided the original author and source are credited. 